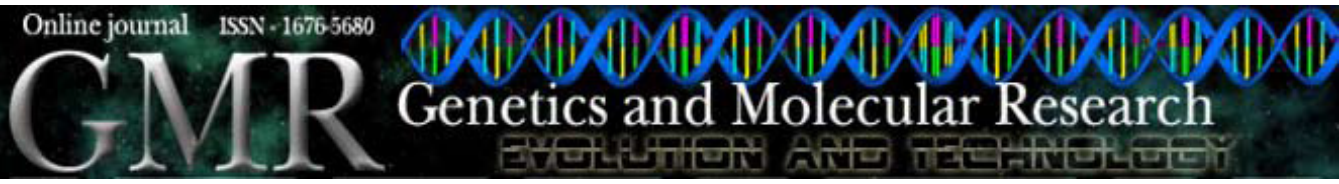

\title{
A rapid method for isolation of total DNA from pathogenic filamentous plant fungi
}

D. González-Mendoza ${ }^{1}$, R. Argumedo-Delira ${ }^{2}$, A. Morales-Trejo ${ }^{1}$, A. Pulido-Herrera ${ }^{1}$, L. Cervantes-Díaz ${ }^{1}$, O. Grimaldo-Juarez ${ }^{1}$ and A. Alarcón ${ }^{2}$

${ }^{1}$ Instituto de Ciencias Agrícolas, Universidad Autónoma de Baja California, Ejido Nuevo León, Baja California, México

${ }^{2}$ Área de Microbiología, Postgrado de Edafología, Colegio de Postgraduados Campus Montecillo, Montecillo, Texcoco, Estado de México

Corresponding author: D. González-Mendoza

E-mail: daniasaf@gmail.com

Genet. Mol. Res. 9 (1): 162-166 (2010)

Received August 31, 2009

Accepted November 20, 2009

Published February 2, 2010

\begin{abstract}
DNA isolation from some fungal organisms of agronomic importance is difficult because they have cell walls or capsules that are relatively unsusceptible to lysis. We have developed a fast DNA isolation protocol for Fusarium oxysporum, which causes fusarium wilt disease in more than 100 plant species, and for Pyrenochaeta terrestris, which causes pink root in onions. This protocol was based on the sodium dodecyl sulfate/ phenol method, without $\beta$-mercaptoethanol and without maceration in liquid nitrogen; it uses phenol/chloroform extraction to remove proteins and co-precipitated polysaccharides. The $\mathrm{A}_{260 / 280}$ absorbance ratios of isolated DNA were around 1.9, suggesting that the DNA fraction was pure and may be used for further analysis. Additionally, the $\mathrm{A}_{260 / 230}$ values were higher than 1.8, suggesting negligible contamination by polysaccharides. The DNA isolated by this protocol is of sufficient quality for molecular applications; this technique could be applied to other organisms that have similar substances that hinder DNA extraction.
\end{abstract}

Key words: Genomic DNA extraction; Fusarium oxysporum;

Pyrenochaeta terrestris; Polymerase chain reaction; Filamentous fungi 


\section{INTRODUCTION}

In Mexico, onion (Allium cepa) holds fourth place in the production of vegetables and is cultivated nearly all over the country; moreover, the country is the principal exporter of this vegetable to the United States (Quintana-Sierra et al., 2005). In Baja California, Mexico, production has increased steadily from approximately 2689 ha in 2005 to 3674 ha in 2007 (SIACON, 2006). However, the presence of diseases caused by pathogenic agents can limit production in Baja California. Pink root disease and fusarium basal rot are two of the important diseases in onion, which are caused by Pyrenochaeta terrestris and Fusarium oxysporum, respectively. These fungi occur in most parts of the world and survive for many years in the soil (Nasr Esfahani and Ansari Pour, 2008). The isolation of pure DNA is crucial for the study of gene expression in these filamentous fungi, because it is a pre-requisite for several molecular biology techniques, including gene isolation by polymerase chain reaction (PCR), Southern blotting, and the construction of genomic DNA libraries.

However, DNA extraction from these filamentous fungi has been described as being rather complicated, because most of the available protocols include the growth of mycelium in liquid culture, followed by maceration in liquid nitrogen, and usually require additional lysis steps, such as mechanical disruption or sonication, enzymatic digestion or use of toxic chemicals (Al-Samarrai and Schmid, 2000; Alaey et al., 2005). Additionally, although some methods do not involve maceration in liquid nitrogen, they are still time consuming and require special columns (Noor Adila et al., 2007). A number of protocols have been established for fungal DNA. However, many of these protocols are apparently suitable for certain groups or morphological forms of fungi but may not be versatile and efficient for extracting nucleic acids from diverse groups of filamentous fungi (Raeder and Broda, 1985; Bolano et al., 2001). Therefore, the objective of this study was to develop an easy and rapid protocol for the isolation of good quality total DNA from filamentous fungi such as $F$. oxysporum and $P$. terrestris biomass.

\section{MATERIAL AND METHODS}

\section{Fungal material}

Fusarium oxysporum strain ICA-F1 and P. terrestris ICA-P1 were grown on potato dextrose agar $\left(\right.$ Baker $\left.^{\circledR}\right)$ on $9-\mathrm{cm}$ diameter Petri dishes at $25^{\circ} \mathrm{C}$ until mycelium completely covered the agar surface. Mycelia were collected by adding sterile distilled water containing $0.05 \%(\mathrm{v} / \mathrm{v})$ Tween 80 to the surface of the culture and gently scrubbing with a sterile spatula. The mycelial suspension was transferred to a $1.5-\mathrm{mL}$ microtube and centrifuged at $3000 \mathrm{~g}$, at $4^{\circ} \mathrm{C}$ for $5 \mathrm{~min}$. The supernatant was discarded and the pellet (100 mg mycelia) was stored at $-80^{\circ} \mathrm{C}$ until further use.

\section{DNA extraction buffer and solutions}

The tubes and bottles were treated with $0.1 \%$ diethyl pyrocarbonate (DEPC, Sigma, Cat. No. D-5758) solution at $37^{\circ} \mathrm{C}$ overnight, autoclaved twice at $121^{\circ} \mathrm{C}$ for $20 \mathrm{~min}$, and then dried at $100^{\circ} \mathrm{C}$ before use. Tips used for DNA extraction were DNase-free and RNase-free (Axygen $^{\circledR}$, USA). The extraction buffer was $3 \%$ SDS (w/v) containing $0.5 \mathrm{mM}$ EDTA, $1.0 \mathrm{M}$ 
$\mathrm{NaCl}$, and $0.1 \mathrm{mM}$ hydroxymethyl-hydrochloride (Tris- $\mathrm{HCl}, \mathrm{pH} 8.0$ ). Additionally, a mixture of chloroform/phenol $(1: 1, \mathrm{v} / \mathrm{v})$ was also prepared.

\section{DNA extraction procedure}

Extraction buffer $(0.2 \mathrm{~mL})$ was added to $10 \mathrm{mg}$ of each fungal mycelium and the suspension shaken vigorously for $15 \mathrm{~s}$. Next, $0.2 \mathrm{~mL}$ chloroform-phenol mix was slowly added and incubated at $65^{\circ} \mathrm{C}$ for $5 \mathrm{~min}$. The mixture was cooled to room temperature and centrifuged at $10,000 \mathrm{~g}$, at $4^{\circ} \mathrm{C}$ for $5 \mathrm{~min}$. The supernatant was transferred to a new microtube, and an equal volume of cold absolute isopropanol or ethanol was added and the contents mixed thoroughly for precipitating total DNA at $-20^{\circ} \mathrm{C}$ for $20 \mathrm{~min}$; the mixture was then centrifuged at $10,000 \mathrm{~g}$ for 10 min. The pellet was washed twice with $75 \%$ ethanol and centrifuged at $10,000 \mathrm{~g}$, at $4{ }^{\circ} \mathrm{C}$ for $5 \mathrm{~min}$.

The supernatant was discarded and the pellet was resuspended in $0.03 \mathrm{~mL}$ DEPC-treated MiniQuantum (deionized) water, and stored at $-80^{\circ} \mathrm{C}$ until further use. Concentration, yield, and quality control indices based on absorbance readings at 230, 260, and $280 \mathrm{~nm}\left(\mathrm{~A}_{260 / 280}\right.$ and $\mathrm{A}_{260 / 230}$ ratios) were carried out with $2 \mu \mathrm{L}$ resuspended total DNA. Ten microliters of total DNA solution was loaded onto a $1 \%$ agarose gel, and electrophoresed to separate DNA.

\section{Polymerase chain reaction}

Specific DNA of each fungus was amplified by PCR with Taq DNA polymerase according to manufacturer instructions (Invitrogen, CA, USA). PCR analysis was performed according to the method described by González-Mendoza et al. (2008), and the fungal DNAs $(2 \mu \mathrm{L})$ were used as PCR template. To assess the suitability of isolated DNA, PCR was performed with equal amounts of DNA, using B-actin primers (5-TGTTCACCACCACA GCAGAGCG-3 and 5-CACTGTCCGTCGGGTAACTCG-3). PCR was carried out using the following protocol: $93^{\circ} \mathrm{C}$ for $3 \mathrm{~min}(1 \mathrm{cycle})$ and $50^{\circ} \mathrm{C}$ for $1 \mathrm{~min}$ and $72^{\circ} \mathrm{C}$ for $1 \mathrm{~min}(30$ cycles). The PCR products were electrophoresed using a $1.5 \%(\mathrm{w} / \mathrm{v})$ agarose gel, which was stained with EtBr and visualized under UV light.

\section{RESULTS AND DISCUSSION}

Since the currently available DNA extraction protocols are rather costly and time consuming (Sambrook and Russel, 2001), we adapted a rapid DNA isolation method from plants (GonzálezMendoza et al., 2008) combining chemical reagent digestion without mechanical shearing for lysing the hyphae of either F. oxysporum strain ICA-F1 or P. terrestris followed by DNA isolation.

The isopropanol and ethanol step allowed effective precipitation of DNA, rendering it more stable. In this study, we also found that grinding the biomass in liquid nitrogen produced poor results (data not shown), and therefore, this step was eliminated. Furthermore, high salt concentration (1.0 $\mathrm{M} \mathrm{NaCl}$ ) in the extraction buffer was introduced to avoid preventing or diminishing the dissolution of polysaccharides during the extraction step. In all cases, we obtained good yields of high-quality genomic DNA (Figure 1). In addition, the absorbance ratios $\mathrm{A}_{260 / 280}$ and $\mathrm{A}_{260 / 230}$ were determined to evaluate quantity, quality, and integrity of isolated DNA. The $\mathrm{A}_{260 / 280}$ was 1.9, suggesting that the DNA fraction was pure and may be used for further analysis. In all samples, the $\mathrm{A}_{260 / 230}$ values were higher than 1.8, suggesting negligible contamination by polysaccharides (Table 1). 


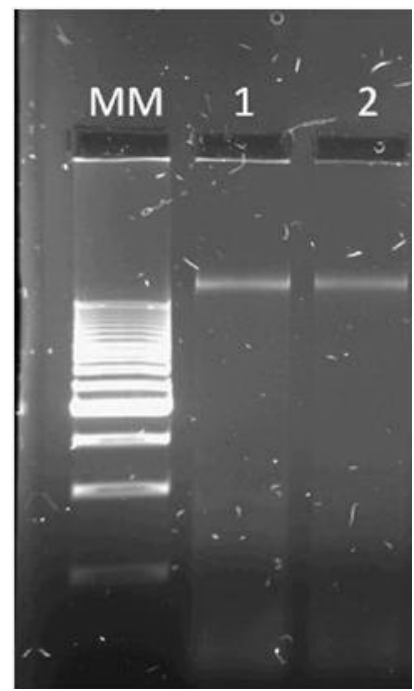

Figure 1. Gel electrophoresis of the total DNA extracted from filamentous fungus. MM=DNA marker (1 kb), lane $1=$ Fusarium oxysporum, and lane $2=$ Pyrenochaeta terrestris.

Table 1. Absorbance ratios and yield of total DNA isolated from fungus.

\begin{tabular}{lccc}
\hline Fungus & $\mathrm{A}_{260 / 280}$ & $\mathrm{~A}_{260 / 230}$ & Yield $(\mu \mathrm{g} / \mathrm{mg}$ fresh weight $)$ \\
\hline Fusarium oxysporum & $1.83 \pm 0.06$ & $1.96 \pm 0.08$ & $9.3 \pm 0.07$ \\
Pyrenochaeta terrestris & $1.87 \pm 0.09$ & $1.90 \pm 0.5$ & $8.6 \pm 0.06$ \\
\hline
\end{tabular}

Data are reported as means $\pm \mathrm{SD}(\mathrm{N}=3)$.

To assess the DNA's purity and its use for basic molecular analysis, PCR amplification of a fragment of the Actin gene present in both fungi was carried out. Amplification produced a single band of approximately 200 bp specific for the Actin gene (Figure 2).

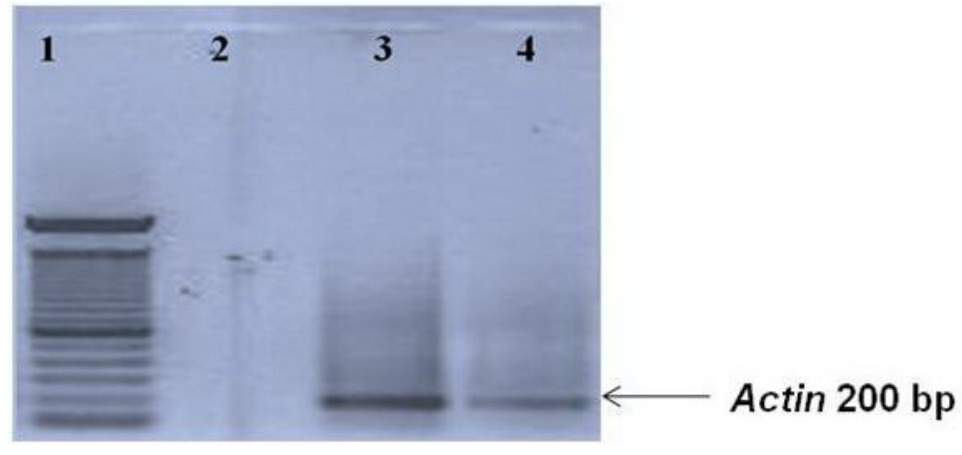

Figure 2. Agarose electrophoresis of the polymerase chain reaction products. Lane $1=$ DNA marker; lane $2=$ negative control; lanes 3 and 4 =Actin gene, 200 bp on Fusarium oxysporum and Pyrenochaeta terrestris, respectively. 
In addition, one of the advantages of this procedure is that the omission of maceration reduces sample handling, minimizing the ristk of contamination between samples. This is particularly important in work involving amplification by PCR. Additionally, this protocol provides a rapid, reliable, and low-cost alternative to the existing DNA purification protocols used in research and clinical laboratories (Liu et al., 2000; Pfaza et al., 2004). Therefore, the proposed protocol is an efficient $(<2 \mathrm{~h})$ and inexpensive procedure for the isolation of good-quality DNA from $F$. oxysporum strain ICA-F1 and $P$. terrestris strain ICA-P1 for molecular assays.

\section{ACKNOWLEDGMENTS}

Research supported by the Programa de Mejoramiento del Profesorado (PROMEP) convocatoria 2008, incorporación de nuevos profesores de tiempo completo.

\section{REFERENCES}

Al-Samarrai TH and Schmid J (2000). A simple method for extraction of fungal genomic DNA. Lett. Appl. Microbiol. 30: 53-56. Alaey M, Naderi R, Vezvaei A, Khalighi A, et al. (2005). Comparing study between four different methods of genomic DNA extraction from Cyclamen persicum Mill. Int. J. Agric. Biol. 7: 882-884.

Bolano A, Stinchi S, Preziosi R, Bistoni F, et al. (2001). Rapid methods to extract DNA and RNA from Cryptococcus neoformans. FEMS Yeast Res. 1: 221-224.

González-Mendoza D, Moreno AQ and Zapata-Pérez O (2008). An improved method for the isolation of total RNA from Avicennia germinans leaves. Z. Naturforsch. C. 63: 124-126.

Liu D, Coloe S, Baird R and Pederson J (2000). Rapid mini-preparation of fungal DNA for PCR. J. Clin. Microbiol. $38: 471$.

Nasr Esfahani M and Ansari Pour B (2008). Differences in resistance in onion cultivars to pink root rot disease in Iran. $J$. Gen. Plant Pathol. 74: 46-52.

Noor Adila AK, Farah Diba AB, Zamri Z, Wan Mohtar WY, et al. (2007). Comparison of methods for isolating high quality DNA and RNA from an oleaginous fungus Cunninghamella bainieri strain 2a1. Mal. J. Microbiol. 3: 7-13.

Pfaza GA, Upchurch R, Brigmon RL, Whitman WB, et al. (2004). Rapid DNA extraction for screening soil filamentous fungi using PCR amplification. Pol. J. Environ. Stud. 13: 315-318.

Quintana-Sierra ME, Robledo-Paz A, Santacruz-Varela A, Gutiérrez-Espinosa A, et al. (2005). Regeneración in vitro de plantas de cebolla (Allium cepa 1.). [In vitro regeneration of onion (Allium cepa 1.) plants]. Agrociencia 39: 647-655.

Raeder U and Broda P (1985). Rapid preparation of DNA from filamentous fungi. Lett. Appl. Microbiol. 1: 17-20.

Sambrook J and Russel DW (2001). Molecular Cloning: a Laboratory Manual. 3rd edn. Cold Spring Harbor Laboratory Press, New York.

Sistema de Información Agropecuaria de Consulta (SIACON) (2006). Centro de Estadística Agropecuaria (C.E.A.). Versión 1.1. Available at [http://www.siap.sagarpa.gob.mx]. Accessed April 2008. 